Research Paper

\title{
Prognostic value of integrin variants and expression in post- operative patients with HBV-related hepatocellular carcinoma
}

\author{
Liming Shang ${ }^{1, *}$, Xinping $\mathrm{Ye}^{1, *}$, Guangzhi Zhu ${ }^{1, *}$, Hao Su${ }^{1}$, Zhixiong Su${ }^{1}$, Bin Chen ${ }^{1}$, \\ Kaiyin Xiao', Lequn $\mathrm{Li}^{2}$, Minhao Peng ${ }^{1}$ and Tao Peng ${ }^{1}$ \\ ${ }^{1}$ Department of Hepatobiliary Surgery, The First Affiliated Hospital of Guangxi Medical University, Nanning, China \\ ${ }^{2}$ Department of Hepatobiliary Surgery, Affiliated Tumor Hospital of Guangxi Medical University, Nanning, China \\ "These authors have contributed equally to this work \\ Correspondence to: Tao Peng, email: pengtaogmu@163.com \\ Keywords: integrin, SNPs, ITGA5, ITGB5, hepatocellular carcinoma \\ Received: January 17, $2017 \quad$ Accepted: June 20,2017 Published: August 10, 2017 \\ Copyright: Shang et al. This is an open-access article distributed under the terms of the Creative Commons Attribution License 3.0 \\ (CC BY 3.0), which permits unrestricted use, distribution, and reproduction in any medium, provided the original author and source \\ are credited.
}

\section{ABSTRACT}

Integrins are a large family of cell surface receptors that bind extracellular matrix proteins and participate in cancer progression. However, the prognostic value of integrin family genes in post-operative patients with HBV-related hepatocellular carcinoma (HCC) remains unknown. In this study, we investigated 18 single nucleotide polymorphisms (SNPs) in integrin family genes and found that the AG/GG genotypes at rs988574 in ITGA1 predicted a better prognosis compared to carriers of the AA genotype $(P=0.025, \mathrm{HR}=0.69,95 \% \mathrm{CI}=0.50-0.96)$. Moreover, rs988574 genotype combined with serum level of AFP had a better prognostic value in HBV-related HCC patients $(P=0.026, \mathrm{HR}=1.75,95 \% \mathrm{CI}=1.07-2.85)$. Furthermore, we compared the expression of 24 integrin family genes in HBV-related HCC tissues and adjacent normal tissues. Survival analysis demonstrated that expression of three of the family members, ITGA5, ITGB5 and ITGA2B, were significantly associated with the overall survival (OS) or relapse-free survival (RFS) of HBV-related HCC patients. Additionally, patients with lower expression of both ITGA5 and ITGB5 had the best OS and RFS ( $P$ $=0.017$ and $P=0.002$, respectively). Our study demonstrated that rs988574 of ITGA1 and the expression of ITGA5, ITGB5 and ITGA2B are potential independent prognostic bio-markers and therapeutic targets for HBV-related HCC patients and may be useful for the diagnosis of HBV-related HCC.

\section{INTRODUCTION}

Hepatocellular carcinoma (HCC) is the second leading cause of cancer-related death worldwide [1]. More than 500,000 patients are newly diagnosed with HCC every year, and $50 \%$ of all cases and deaths are in China $[2,3]$. Among these, most are hepatitis B virus (HBV)related HCC patients. Although advances in treatment, especially in surgical techniques and molecular targeted therapy, have improved the survival rates of HCC patients, the long term prognosis after surgical resection remains very poor [4-6]. Thus, early diagnosis and treatment are very important to improve the prognosis of $\mathrm{HCC}$ patients [7-10]. Multiple clinical factors have been used as indicators for the diagnosis and evaluation of $\mathrm{HCC}$, for instance, drinking status, chronic $\mathrm{HBV}$ or hepatitis $\mathrm{C}$ virus (HCV) infections, large tumor size, vascular invasion, positive portal vein thrombosis, serum alpha fetoprotein (AFP) and Barcelona Clinic Liver Cancer (BCLC) stage [11-13]. Current indicators used to predict HCC outcomes and the prognosis of HCC patients are not sufficient. Thus, it is urgent to identify potential biomarkers for improving the efficacy of prognosis prediction and the clinical outcomes of HCC patients.

The integrin family consists of $18 \alpha$ and $8 \beta$ subunits that form 24 known $\alpha \beta$-heterodimers. Both $\alpha$ and $\beta$ 
subunits have a large $\mathrm{NH}_{2}$-terminal extracellular domain, a single transmembrane domain and a short non-catalytic cytoplasmic tail $[14,15]$. Integrins are involved in a wide range of biological activities and pathological processes, especially carcinogenesis and cancer progression [16, 17]. They regulate cell-cell and cell-ECM interactions, and this 'outside-in' signaling activates a number of signaling pathways that are important in the regulation of cell shape, survival, gene transcription and migration [18, 19]. They also interact with growth factors or chemokines to regulate cell growth and differentiation $[14,20]$. Thus, targeting integrins and their associated signaling pathways, which are involved in tumor proliferation, migration, invasion and metastasis, may be a novel strategy for the diagnosis and treatment of cancers as well as certain non-neoplastic conditions [21]. Studies have also reported that effective blockage of integrins and ECM interactions impairs several important aspects of tumor biology and increases sensitivity to existing chemotherapy [22, 23]. Antiintegrin antagonists used in combination with current chemotherapeutic drugs have been shown to have roles in preventing drug resistance and tumor relapse [24].

In this study, we evaluated the prognostic predictive value of integrin family genes and ITGA1 single nucleotide polymorphism (SNP) rs988574 in HBVrelated HCC patients by performing prognostic analysis in 221 newly diagnosed pathologically confirmed HBVrelated HCC patients. First, we found that ITGA5 and ITGB5 are more highly expressed in HBV-related HCC tissues than adjacent normal tissues. Conversely, ITGA2B is more highly expressed in adjacent normal tissues than in HBV-related HCC tissues. We also found that higher expression of ITGA5, ITGB5 and ITGA2B predicted worse prognosis in HBV-related HCC patients, and patients with lower expression of both ITGA5 and ITGB5 had the best prognosis. In addition, we found that patients carrying the AG or GG genotypes at rs988574 had better prognosis than those with the AA genotype.

\section{RESULTS}

\section{Patient characteristics and clinical predictors}

The clinical and pathologic characteristics of the patients are shown in Table 1. Overall, 55 female patients and 430 male patients were included. Among them, 307 were Han Chinese and 178 were minorities. The median survival times were 57 and 51 months for patients aged $\leq 46$ years and $>46$ years, respectively. As shown in Table 1 univariate analysis indicated that patients with BCLC stages $\mathrm{B}$ and $\mathrm{C}(\mathrm{HR}=1.92,95 \% \mathrm{CI}=1.35-2.73$; $\mathrm{HR}=3.1,95 \% \mathrm{CI}=2.31-4.16$, respectively), Child-Pugh class $\mathrm{B}(\mathrm{HR}=1.68,95 \% \mathrm{CI}=1.21-2.33)$, non-radical resection $(\mathrm{HR}=0.76,95 \% \mathrm{CI}=0.59-0.99)$, non-antiviral therapies $(\mathrm{HR}=0.72,95 \% \mathrm{CI}=0.53-0.98), \mathrm{AFP} \geq 300 \mathrm{ng} /$ $\mathrm{ml}(\mathrm{HR}=1.30,95 \% \mathrm{CI}=0.99-1.71)$, tumor size $\geq 5 \mathrm{~cm}$
$(\mathrm{HR}=2.04,95 \% \mathrm{CI}=1.49-2.80)$, multiple tumors $(\mathrm{n}$ $>1)(\mathrm{HR}=1.61,95 \% \mathrm{CI}=1.23-2.12)$ and presence of PVTT $(\mathrm{HR}=2.40,95 \% \mathrm{CI}=1.12-5.12)$ had higher risk of death when compared with patients with BCLC stage A, child-Pugh class $\mathrm{A}$, radical resection, antiviral therapies, AFP $<300 \mathrm{ng} / \mathrm{ml}$, tumor size $<3 \mathrm{~cm}$, single tumor $(\mathrm{n}=1)$ and absence of PVTT, respectively. In addition, clinical features including age, gender, race, BMI, drinking status, smoking status, adjuvant TACE and cirrhosis were found to have no effect on the OS of HBV-related HCC patients in our study.

\section{ITGA1 SNP rs988574-AA predicted worse OS in HBV-related HCC patients}

The SNP functional prediction results showed that rs988574 located in a splice site and the non-synonymous mutation was possibly damaging for gene expression as predicted by Polyphen in SNP selection tools. In this study, we found that patients carrying the AG/GG alleles of rs988574 had a significantly better prognosis when compared to patients with the AA genotype. Cox proportional hazards regression analysis showed that rs988574 was significantly associated with prognosis when adjusting for age, gender, race, smoking status, drinking status, BMI, child-Pugh class, cirrhosis, BCLC stage, pathological grade, TACE status post hepatectomy, antiviral therapy after hepatectomy, radical resection and serum AFP levels (Tables 2 and 3). Figure 1A shows that patients with the AG genotype had a significantly favorable OS, compared to patients with the AA genotype. Additionally, when combining carriers of the AG and GG alleles, patients with the AA genotype had a worse prognosis (Figure 1B). The adjusted survival curve shows a significant difference in OS between patients with the AG and GG genotypes of rs988574 compared to those with the AA genotype $(P=0.025, \mathrm{HR}=0.6995 \% \mathrm{CI}=$ 0.50-0.96; Table 3).

Stratified analysis also utilized to investigate the association between clinicopathological features and HBV-related HCC outcomes. In stratified analyses, the AG/GG genotype ofrs988574 significantly decreased risk of death among HBV-related HCC patients with BCLC A stage, intrahepatic metastasis, advanced pathological grade, adjuvant TACE and patients without PVTT and vascular invasion (Figure 2) after hepatectomy, compared to patients with the AA genotype.

\section{Prognostic value of rs988574 combined with serum AFP level on OS in HBV-related HCC patients}

In this study, we further analyzed the combined effect of rs988574 and serum AFP level on the prognosis of patients. According to rs988574 genotype and serum AFP level, patients were classified into four groups: 
Table 1: Univariate Cox proportional hazards analysis of clinicopathological characteristics and overall survival in HBV-related HCC patients

\begin{tabular}{|c|c|c|c|c|}
\hline \multirow[t]{2}{*}{ Variables } & \multirow[t]{2}{*}{ Patients $(n=485)$} & \multicolumn{3}{|c|}{ OS } \\
\hline & & MST (months) & $H R *(95 \% \mathrm{CI})$ & $\mathbf{P} *$ \\
\hline \multicolumn{5}{|l|}{ Age (yr) } \\
\hline$\leq 46$ & 260 & 57 & Ref. & \\
\hline$>46$ & 225 & 51 & $0.97(0.74-1.25)$ & 0.789 \\
\hline \multicolumn{5}{|l|}{ Gender } \\
\hline male & 430 & 51 & Ref. & \\
\hline female & 55 & 80 & $0.75(0.47-1.18)$ & 0.208 \\
\hline \multicolumn{5}{|l|}{ Race } \\
\hline Han & 307 & 68 & Ref. & \\
\hline Minority & 178 & 51 & $1.10(0.84-1.45)$ & 0.473 \\
\hline \multicolumn{5}{|l|}{ BMI } \\
\hline$\leq 25$ & 401 & 58 & Ref. & \\
\hline$>25$ & 84 & 57 & $0.95(0.68-1.32)$ & 0.737 \\
\hline \multicolumn{5}{|c|}{ Smoking status } \\
\hline None & 318 & 71 & Ref. & \\
\hline Ever & 167 & 42 & $1.20(0.91-1.57)$ & 0.191 \\
\hline \multicolumn{5}{|c|}{ Drinking status } \\
\hline None & 295 & 71 & Ref. & \\
\hline Ever & 190 & 48 & $1.18(0.91-1.53)$ & 0.219 \\
\hline \multicolumn{5}{|c|}{ Adjuvant TACE ${ }^{a}$} \\
\hline No & 212 & 88 & Ref. & \\
\hline Yes & 273 & 47 & $1.14(0.87-1.49)$ & 0.340 \\
\hline \multicolumn{5}{|l|}{ BCLC stage } \\
\hline A & 284 & 95 & Ref. & $<0.001$ \\
\hline B & 80 & 47 & $1.92(1.35-2.73)$ & $<0.001$ \\
\hline $\mathrm{C}$ & 121 & 24 & $3.10(2.31-4.16)$ & $<0.001$ \\
\hline \multicolumn{5}{|c|}{ Child-Pugh class } \\
\hline A & 403 & 65 & Ref. & \\
\hline B & 82 & 34 & $1.68(1.21-2.33)$ & 0.002 \\
\hline \multicolumn{5}{|l|}{ Cirrhosis } \\
\hline No & 58 & 82 & Ref. & \\
\hline Yes & 426 & 51 & $1.21(0.80-1.84)$ & 0.361 \\
\hline \multicolumn{5}{|c|}{ Antiviral therapy ${ }^{\mathrm{b}}$} \\
\hline No & 315 & 47 & Ref. & \\
\hline Yes & 170 & 81 & $0.72(0.53-0.98)$ & 0.036 \\
\hline
\end{tabular}




\begin{tabular}{|c|c|c|c|c|}
\hline \multirow[t]{2}{*}{ Variables } & \multirow[t]{2}{*}{ Patients $(n=485)$} & \multicolumn{3}{|c|}{ OS } \\
\hline & & MST (months) & $H R *(95 \% C I)$ & $\mathbf{P} *$ \\
\hline \multicolumn{5}{|l|}{ AFP } \\
\hline$\leq 400(\mathrm{ng} / \mathrm{ml})$ & 247 & 63 & Ref. & \\
\hline$>400(\mathrm{ng} / \mathrm{ml})$ & 202 & 42 & $1.30(0.99-1.71)$ & 0.059 \\
\hline missing & 36 & & & \\
\hline \multicolumn{5}{|l|}{ Radical resection } \\
\hline No & 205 & 41 & Ref. & \\
\hline Yes & 268 & 74 & $0.76(0.59-0.99)$ & 0.044 \\
\hline missing & 12 & & & \\
\hline \multicolumn{5}{|l|}{ Pathological grade } \\
\hline Well & 27 & 79 & Ref. & 0.761 \\
\hline Moderately & 372 & 51 & $1.25(0.68-2.30)$ & 0.470 \\
\hline Poorly & 13 & NA & $1.15(0.40-3.31)$ & 0.797 \\
\hline missing & 73 & & & \\
\hline \multicolumn{5}{|c|}{ Oncological behavior } \\
\hline \multicolumn{5}{|l|}{ Tumor size } \\
\hline$\leq 5 \mathrm{~cm}$ & 155 & 123 & Ref. & \\
\hline$>5 \mathrm{~cm}$ & 330 & 40 & $2.04(1.49-2.80)$ & $<0.001$ \\
\hline \multicolumn{5}{|l|}{ No. of tumors } \\
\hline Single $(\mathrm{n}=1)$ & 356 & 63 & Ref. & \\
\hline Multiple (n > 1) & 129 & 35 & $1.61(1.23-2.12)$ & 0.001 \\
\hline \multicolumn{5}{|l|}{ Regional invasion } \\
\hline Absence & 412 & 68 & Ref. & \\
\hline Presence & 73 & 37 & $1.62(1.137-2.30)$ & 0.007 \\
\hline \multicolumn{5}{|c|}{ Intrahepatic metastasis } \\
\hline Absence & 264 & 81 & Ref. & \\
\hline Presence & 221 & 35 & $1.80(1.38-2.33)$ & $<0.001$ \\
\hline \multicolumn{5}{|l|}{ Vascular invasion } \\
\hline Absence & 399 & 78 & Ref. & \\
\hline Presence & 86 & 18 & $3.16(2.35-4.25)$ & $<0.001$ \\
\hline \multicolumn{5}{|l|}{ PVTT } \\
\hline No & 409 & 76 & Ref. & $<0.001$ \\
\hline vp1 & 11 & 28 & $2.40(1.12-5.12)$ & 0.024 \\
\hline vp2 & 17 & 17 & 3.44 (1.99-5.96) & $<0.001$ \\
\hline vp3 & 40 & 17 & $2.89(1.96-4.27)$ & $<0.001$ \\
\hline vp4 & 8 & 8 & $5.84(2.72-12.54)$ & $<0.001$ \\
\hline
\end{tabular}

Note: *HR and P-value for univariate survival analysis; ${ }^{a}$ Adjuvant TACE post hepatectomy; ${ }^{b}$ Adjuvant antiviral therapy post hepatectomy;

OS, overall survival; MST, median survival time; HR, hazard ratio; 95\% CI, 95\% confidence interval; Ref., reference; PVTT, portal vein tumor thrombus. 
Table 2: Multivariate Cox proportional hazards ratio analysis of ITGA1 SNPs and overall survival or relapse free survival in HBV-related HCC patients

\begin{tabular}{|c|c|c|c|c|c|c|c|c|}
\hline \multirow[t]{2}{*}{ SNP } & \multirow[t]{2}{*}{ Chr } & \multirow[t]{2}{*}{ Position } & \multirow[t]{2}{*}{ Gene } & \multirow[t]{2}{*}{ Allele } & \multirow[t]{2}{*}{ Function } & \multirow[t]{2}{*}{ MAF } & \multicolumn{2}{|l|}{ os } \\
\hline & & & & & & & Log-rank P & $\operatorname{Cox} \mathbf{P}$ \\
\hline rs 1531545 & 5 & 52193287 & ITGA1 & $\mathrm{C} / \mathrm{T}$ & Synonymous & 0.34 & 0.208 & 0.301 \\
\hline rs4145748 & 5 & 52201722 & ITGA1 & $\mathrm{C} / \mathrm{T}$ & Nonsynonymous & 0.09 & 0.414 & 0.455 \\
\hline rs2279587 & 5 & 52214581 & ITGA1 & $\mathrm{G} / \mathrm{A}$ & Nonsynonymous & 0.11 & 0.257 & 0.312 \\
\hline rs 12520591 & 5 & 52229745 & ITGA1 & $\mathrm{T} / \mathrm{G}$ & Nonsynonymous & 0.11 & 0.378 & 0.356 \\
\hline rs988574 & 5 & 52240810 & ITGA1 & $\mathbf{A} / \mathbf{G}$ & Nonsynonymous & 0.14 & 0.002 & $0.043 \mathfrak{f}$ \\
\hline rs2230392 & 17 & 48155425 & ITGA3 & $\mathrm{G} / \mathrm{A}$ & Nonsynonymous & 0.29 & 0.219 & 0.374 \\
\hline rs1143674 & 2 & 182374534 & ITGA4 & $\mathrm{A} / \mathrm{G}$ & Synonymous & 0.36 & 0.453 & 0.499 \\
\hline rs1143676 & 2 & 182395345 & ITGA4 & $\mathrm{G} / \mathrm{A}$ & Nonsynonymous & 0.12 & 0.182 & 0.386 \\
\hline rs 7562325 & 2 & 182399097 & ITGA4 & $\mathrm{T} / \mathrm{C}$ & Synonymous & 0.36 & 0.420 & 0.429 \\
\hline rs 11895564 & 2 & 173339808 & ITGA6 & $\mathrm{G} / \mathrm{A}$ & Nonsynonymous & 0.06 & 0.516 & 0.604 \\
\hline rs1800974 & 12 & 56089357 & ITGA7 & $\mathrm{C} / \mathrm{T}$ & Nonsynonymous & 0.06 & 0.108 & 0.156 \\
\hline rs2298033 & 10 & 15649710 & ITGA8 & $\mathrm{G} / \mathrm{A}$ & Nonsynonymous & 0.06 & 0.886 & 0.901 \\
\hline rs 2507941 & 3 & 37536056 & ITGA9 & $\mathrm{C} / \mathrm{T}$ & Synonymous & 0.08 & 0.737 & 0.825 \\
\hline rs 267561 & 3 & 37574951 & ITGA9 & $\mathrm{G} / \mathrm{A}$ & Nonsynonymous & 0.22 & 0.284 & 0.355 \\
\hline rs2274616 & 1 & 145536082 & ITGA10 & $\mathrm{G} / \mathrm{A}$ & Nonsynonymous & 0.07 & 0.479 & 0.622 \\
\hline rs2230433 & 16 & 30518041 & ITGAL & $\mathrm{G} / \mathrm{C}$ & Nonsynonymous & 0.19 & 0.766 & 0.812 \\
\hline rs871443 & 17 & 73753503 & ITGB4 & $\mathrm{T} / \mathrm{C}$ & Nonsynonymous & 0.37 & 0.580 & 0.635 \\
\hline rs2291089 & 3 & 124515636 & ITGB5 & $\mathrm{C} / \mathrm{T}$ & Nonsynonymous & 0.10 & 0.299 & 0.427 \\
\hline
\end{tabular}

Note: Cox P adjusted for age, gender, BMI, race, smoking status, drinking status, Child-Pugh class, cirrhosis, BCLC stage, pathological grade, TACE status post hepatectomy, antiviral therapy after hepatectomy, radical resection, serum AFP levels, intrahepatic metastasis, vascular invasion and PVTT. £Sequencing map of rs988574 was shown in Supplementary Figure 1.

SNP, single nucleotide polymorphism; Chr, chromosome; MAF, minor allele frequency; OS, overall survival.

$\mathrm{AFP} \leq 400 \mathrm{ng} / \mathrm{mL}$ with $\mathrm{AG} / \mathrm{GG}$ genotype, $\mathrm{AFP} \leq 400$ $\mathrm{ng} / \mathrm{mL}$ with AA genotype, AFP $>400 \mathrm{ng} / \mathrm{mL}$ with AG/ GG genotype and AFP $>400 \mathrm{ng} / \mathrm{mL}$ with AA genotype (Table 4). Multivariate Cox regression analysis indicated that, as compared to patients with AG/GG genotype and low serum AFP (AFP $\leq 400 \mathrm{ng} / \mathrm{ml})$, patients with the AA genotype and a high serum AFP (AFP $>400 \mathrm{ng} / \mathrm{mL})$ had a significantly higher risk for death (adjusted $P=0.026$, adjusted $\mathrm{HR}=1.75,95 \% \mathrm{CI}=1.07-2.85$; Table 4 and Figure 1C).

\section{The mRNA expression level of integrins in HCC tissues and adjacent normal tissues}

The integrin family consists of 24 genes, widely studied in the progression of various cancers. To clarify the expression pattern of integrin family members in HBVrelated $\mathrm{HCC}$ patients, we compared the mRNA expression levels between HBV-related HCC tissues and adjacent normal tissues. The results showed that nine of the integrin gene family members have a higher expression in HBVrelated HCC tissues compared to adjacent normal tissues (Figure 3A; $P<0.001$ ). In a multivariate Cox proportional hazards ratio analysis adjusting for age, gender, cirrhosis, BCLC stage and serum AFP levels, we found that among the 24 integrin family genes, ITGA5, ITGB5 and ITGA2B were significantly associated with prognosis in terms of OS or RFS of patients with HBV-related HCC (Tables 5 and $6 ; P<0.05)$. Then, we compared the expression of ITGA5, ITGB5 and ITGA2B in $221 \mathrm{HBV}$-related HCC tissues and 221 adjacent normal tissues, and the results showed that ITGA5 and ITGB5 are more highly expressed in HBV-related HCC tissues than adjacent normal tissues, while ITGA2B had a lower expression level in HBVrelated $\mathrm{HCC}$ tissues than adjacent normal tissues (Figure $3 \mathrm{~B} ; P<0.001)$.

The adjusted survival curves showed a significant difference in OS and RFS between patients with higher 
versus lower ITGA5, ITGB5 and ITGA2B expression levels. (Figure 4). The mRNA expression levels of ITGA5, ITGB5 and ITGA2B were independent prognostic indicators in HBV-related $\mathrm{HCC}$ patients (Table 6). Co-expression analysis indicated that ITGA5 mRNA

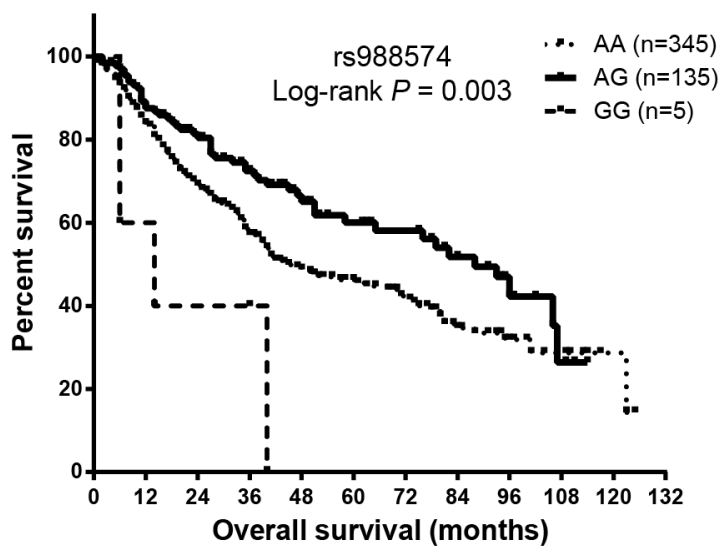

(A) expression had a significantly positive correlation with ITGB5 $(\mathrm{r}=0.32, P<0.001)$ in tumor tissue, whereas $I T G A 2 B$ had a significantly negative correlation with ITGA5 $(\mathrm{r}=-0.142, P=0.035)$ and ITGB5 $(\mathrm{r}=-0.34, P$ $<0.001$ ), respectively.

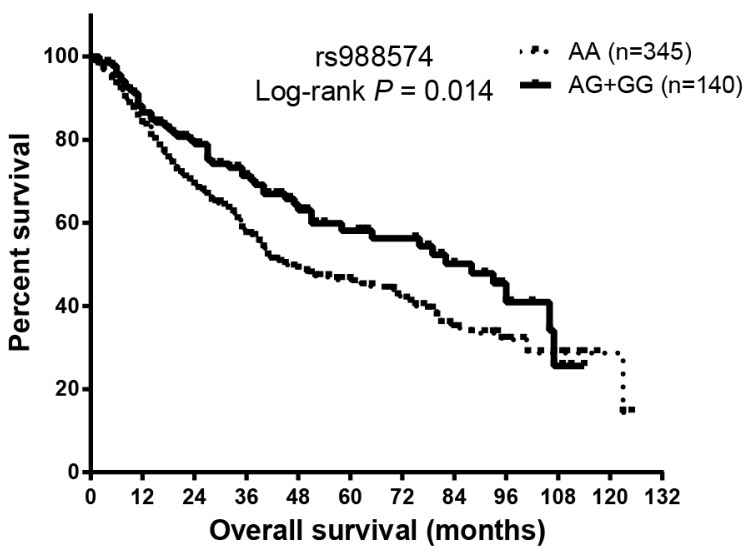

(B)

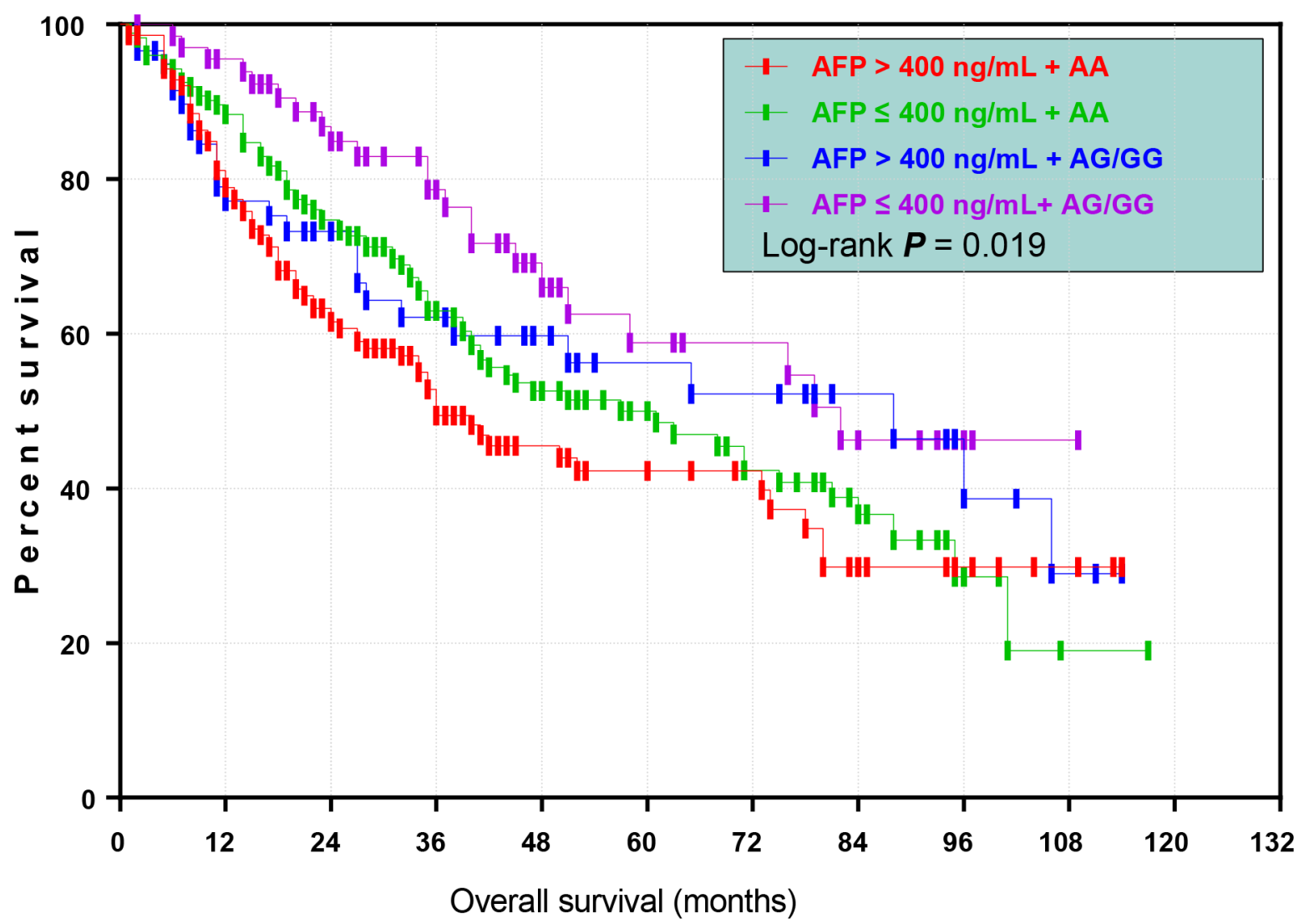

(C)

Figure 1: Prognostic value of ITGA1 SNP rs988574 genotype in HBV-related HCC patients. (A, B) Kaplan-Meier graphs representing the probabilities of overall survival in HCC patients; (C) Kaplan-Meier graph showing the overall survival by rs988574 genotype combined with serum AFP level in HBV-related HCC patients. 
Table 3: Multivariate Cox proportional hazards ratio analysis of ITGA1 SNP rs988574 and overall survival in HBVrelated HCC patients

\begin{tabular}{lcccccc}
\hline SNP & Patients (n=485) & \multicolumn{5}{c}{ OS } \\
\cline { 3 - 7 } & & MST (months) & HR (95\% CI) & $\boldsymbol{P}$ & $\begin{array}{c}\text { Adjusted HR } \\
\text { (95\% CI) }\end{array}$ & ${\text { Adjusted } \boldsymbol{P}^{*}}^{*}$ \\
\hline rs988574 & & & & & \\
AA & 345 & 42 & Ref. & $\mathbf{0 . 0 0 3}$ & Ref. & 0.052 \\
AG & 135 & 88 & $0.65(0.47-0.88)$ & $\mathbf{0 . 0 0 6}$ & $0.67(0.48-0.93)$ & $\mathbf{0 . 0 1 8}$ \\
GG & 5 & 14 & $2.53(0.94-6.83)$ & 0.067 & $1.30(0.40-4.25)$ & 0.659 \\
AG+GG & 140 & 82 & $0.68(0.51-0.93)$ & $\mathbf{0 . 0 1 4}$ & $0.69(0.50-0.96)$ & $\mathbf{0 . 0 2 5}$ \\
\hline
\end{tabular}

Note: *Adjusted for age, gender, BMI, race, smoking status, drinking status, Child-Pugh class, cirrhosis, BCLC stage, pathological grade, TACE status post hepatectomy, antiviral therapy after hepatectomy, radical resection, serum AFP levels, intrahepatic metastasis, vascular invasion and PVTT.

SNP, single nucleotide polymorphism; OS, overall survival; MST, median survival time; HR, hazard ratio; 95\% CI, 95\% confidence interval; Ref., reference.

\section{Prognostic prediction of $I T G A 5$ expression combined with ITGB5 expression in HBV-related HCC patients}

Base on the results of the co-expression and survival analysis for individual integrin genes, we analyzed the prognostic predictive value of combining ITGA5 and $I T G B 5$ expression. The results showed that patients with higher expression of both ITGA5 and ITGB5 had the worst OS and RFS compared to patients with lower expression of these genes (Figure 5 and Table 7; $P=0.017$ and 0.002 , respectively).

\section{DISCUSSION}

In this study, we examined whether genetic polymorphisms in the integrin gene family are associated with the OS of HBV-related HCC patients and explored the expression pattern and prognostic predictive value of these genes using GEO data. We found that the AG/ GG genotypes of rs988574 (ITGA1) are significantly associated with better OS compared with the AA genotype in HBV-related HCC patients. In addition, we found that patients with the AA genotype combined with high serum AFP (AFP $>400 \mathrm{ng} / \mathrm{mL}$ ) predicted the highest risk of death. Additionally, among the 24 integrin family members, nine had higher expression in HBV-related HCC tissues compared to adjacent normal tissues, while the other integrin genes showed the opposite expression pattern. Specifically, the expression of ITGA5 and ITGB5 were higher in HCC tissues than in adjacent tissues. In contrast, the expression of ITGA2B was the opposite, and significantly negative correlation with ITGA5 and ITGB5 in tumor tissue. Furthermore, we found that the expression level of ITGA5, ITGB5 and ITGA2B were associated with the prognosis of HBV-related HCC patients; lower

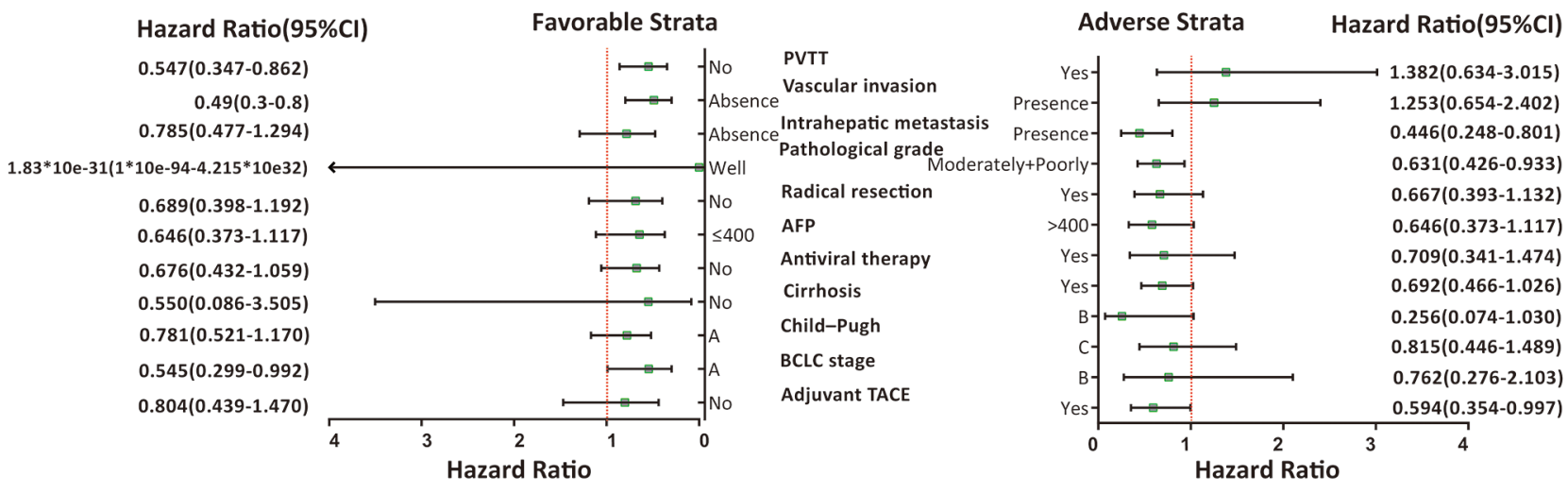

Figure 2: Stratified analysis of association between ITGA1-rs988574 polymorphisms and OS in HBV-related HCC patients. Variables were stratified according to favorable and adverse strata. 
Table 4: Multivariate Cox proportional hazards ratio analysis combining ITGA1 SNP rs988574 and APF level for overall survival in HBV-related HCC patients

\begin{tabular}{|c|c|c|c|c|c|}
\hline SNP & MST (months) & HR $(95 \% C I)$ & $\mathbf{P}$ & HR * $(95 \% C I)$ & $\mathbf{P}^{*}$ \\
\hline \multicolumn{6}{|l|}{ rs988574 } \\
\hline $\begin{array}{l}\mathrm{AFP} \leq 400 \\
(\mathrm{ng} / \mathrm{mL})+\mathrm{AG} / \\
\mathrm{GG}\end{array}$ & 79 & Ref. & 0.019 & Ref. & 0.094 \\
\hline $\begin{array}{l}\mathrm{AFP}>400 \\
(\mathrm{ng} / \mathrm{mL})+\mathrm{AG} / \\
\mathrm{GG}\end{array}$ & 88 & $1.41(0.80-2.48)$ & 0.230 & $1.23(0.68-2.22)$ & 0.490 \\
\hline $\begin{array}{l}\mathrm{AFP} \leq 400 \\
(\mathrm{ng} / \mathrm{mL})+\mathrm{AA}\end{array}$ & 57 & $1.59(1.00-2.53)$ & 0.048 & $1.60(0.99-2.59)$ & 0.056 \\
\hline $\begin{array}{l}\mathrm{AFP}>400 \\
(\mathrm{ng} / \mathrm{mL})+\mathrm{AA}\end{array}$ & 36 & $2.05(1.28-3.27)$ & 0.003 & $1.75(1.07-2.85)$ & 0.026 \\
\hline
\end{tabular}

Note:"Adjusted for age, gender, BMI, race, smoking status, drinking status, Child-Pugh class, cirrhosis, BCLC stage, pathological grade, TACE status post hepatectomy, antiviral therapy after hepatectomy, radical resection, intrahepatic metastasis, vascular invasion and PVTT.

SNP, single nucleotide polymorphism; MST, median survival time; HR, hazard ratio; 95\% CI, 95\% confidence interval; Ref., reference.

expression of these genes predicted a better OS and RFS compared with higher expression. Furthermore, we found that patients with the combination of lower expression of both ITGA5 and ITGB5 had the best OS and RFS.

Our SNP functional prediction results show that rs988574 disrupts a splice site, and this non-synonymous mutation was possibly damaging for gene expression as predicted by Polyphen in SNP selection tools. This may a potential mechanism that AA polymorphism of rs988574 affects functionality of ITGA1 in respect to the HBV-related HCC. Moreover, we demonstrated that the SNP rs988574 in ITGA1 may serve as an independent prognostic marker in HBV-related HCC patients. Once validated, these genes, either alone or in combination with

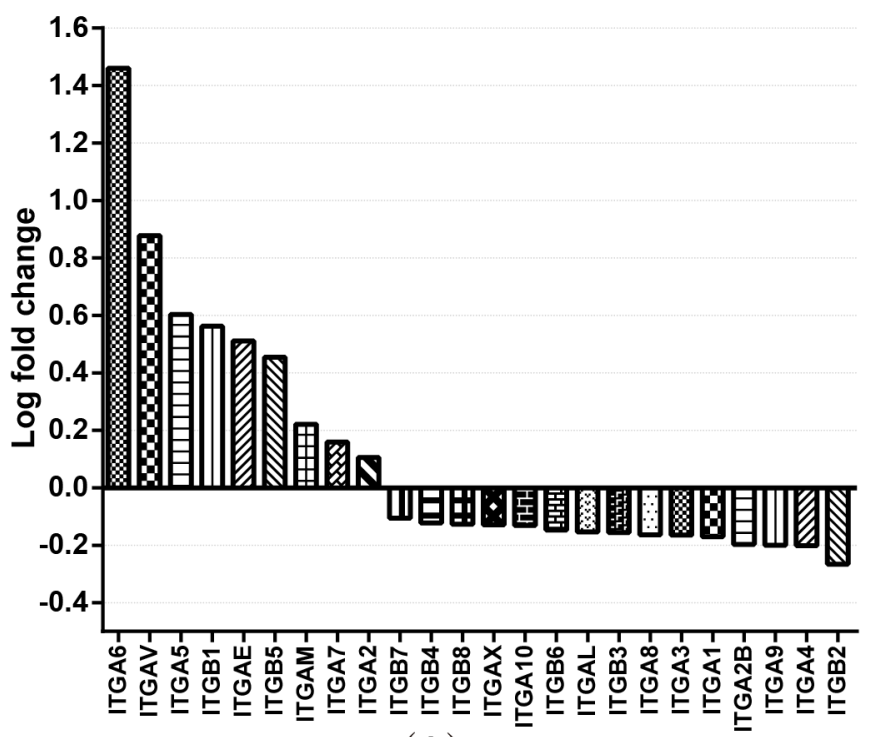

(A)

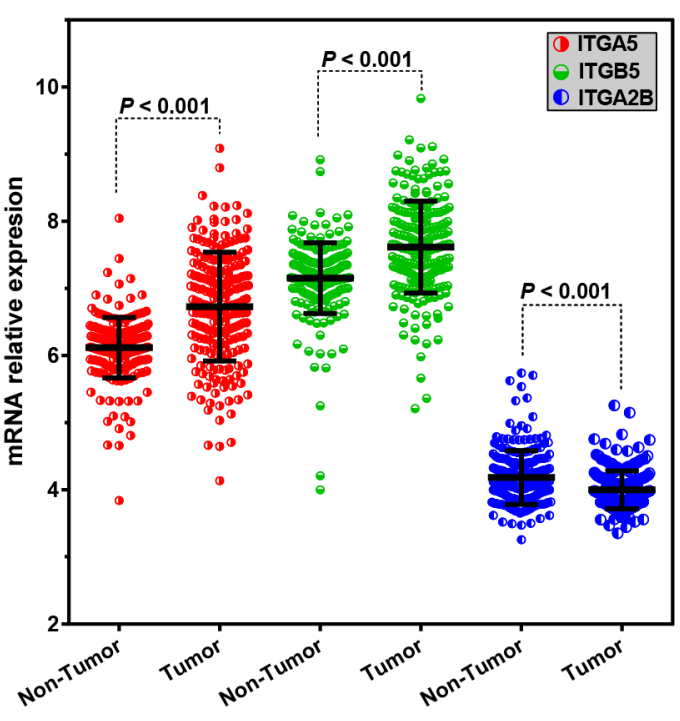

(B)

Figure 3: Integrin family genes' expression levels in HCC tissues and adjacent normal tissues. (A) Histogram of log-fold change showing the 24 integrin family members' expression levels in HBV-related HCC tissues compared with adjacent normal tissues. (B) Comparison of the expression of ITGA5, ITGB5 and ITGA2B in $221 \mathrm{HBV}$-related HCC tissues and adjacent normal tissues. P-value indicates statistical significance analyzed by Student's t-test. 
Table 5: Multivariate Cox proportional hazards ratio analysis of integrin genes expression and overall survival or relapse free survival in HBV-related HCC patients

\begin{tabular}{|c|c|c|c|c|}
\hline \multirow[t]{2}{*}{ Integrins } & \multicolumn{2}{|c|}{ OS } & \multicolumn{2}{|c|}{ RFS } \\
\hline & Log-rank P & $\operatorname{Cox} \mathbf{P}^{*}$ & Log-rank $P$ & $\operatorname{Cox} \mathbf{P}^{*}$ \\
\hline ITGA1 & 0.861 & 0.438 & 0.793 & 0.471 \\
\hline ITGA2 & 0.241 & 0.762 & 0.305 & 0.727 \\
\hline ITGA2B & 0.230 & 0.064 & 0.172 & 0.032 \\
\hline ITGA3 & 0.209 & 0.217 & 0.721 & 0.997 \\
\hline ITGA4 & 0.138 & 0.327 & 0.069 & 0.095 \\
\hline ITGA5 & 0.013 & 0.041 & 0.003 & 0.006 \\
\hline ITGA6 & 0.885 & 0.337 & 0.377 & 0.089 \\
\hline ITGA7 & 0.126 & 0.169 & 0.438 & 0.407 \\
\hline ITGA8 & 0.579 & 0.826 & 0.877 & 0.784 \\
\hline ITGA9 & 0.481 & 0.813 & 0.094 & 0.072 \\
\hline ITGA10 & 0.509 & 0.567 & 0.308 & 0.510 \\
\hline ITGAE & 0.528 & 0.464 & 0.906 & 0.913 \\
\hline ITGAL & 0.803 & 0.913 & 0.562 & 0.672 \\
\hline ITGAM & 0.463 & 0.677 & 0.439 & 0.777 \\
\hline ITGAV & 0.411 & 0.172 & 0.825 & 0.692 \\
\hline ITGAX & 0.877 & 0.079 & 0.517 & 0.879 \\
\hline ITGB1 & 0.403 & 0.822 & 0.340 & 0.846 \\
\hline ITGB2 & 0.902 & 0.654 & 0.514 & 0.298 \\
\hline ITGB3 & 0.614 & 0.154 & 0.042 & 0.064 \\
\hline ITGB4 & 0.716 & 0.983 & 0.735 & 0.407 \\
\hline ITGB5 & 0.016 & 0.048 & 0.069 & 0.042 \\
\hline ITGB6 & 0.434 & 0.928 & 0.625 & 0.768 \\
\hline ITGB7 & 0.451 & 0.635 & 0.523 & 0.591 \\
\hline ITGB8 & 0.945 & 0.919 & 0.615 & 0.760 \\
\hline
\end{tabular}

Note: The 75th percentile of mRNA expression in the total population was used as the cutoff point to define lower and higher expression groups. "Cox P adjusted for age, gender, cirrhosis, BCLC stage and serum AFP levels.

OS, overall survival; RFS, relapse-free survival.

each other or other traditional clinical-prognostic factors, may be used as new targets for the treatment of HBVrelated HCC patients.

Integrins are a large family of cell surface receptors that bind ECM proteins to regulate attachment, cell proliferation, differentiation, motility and other essential cell functions [25]. They are critically important for both health and disease by participating in diverse human pathologies including thrombotic diseases, infectious diseases, inflammation, fibrosis and cancer [24]. Integrins play an important role in cancer survival, proliferation, growth and metastasis [26-28]. Apart from their correlation with cancer prognosis, integrins can also protect cells from stress, leading to cancer cell resistance to radioand chemotherapy [29]. Additionally, integrin inhibition has been shown to enhance the cytotoxic efficacy of 
Table 6: Multivariate Cox proportional hazards ratio analysis of $I T G A 5, I T G B 5$ and $I T G A 2 B$ expression and overall survival or relapse-free survival in $\mathrm{HBV}$-related $\mathrm{HCC}$ patients

\begin{tabular}{|c|c|c|c|c|c|c|c|}
\hline \multirow[t]{2}{*}{ Gene } & \multirow{2}{*}{$\begin{array}{c}\text { Patients } \\
(n=221)\end{array}$} & \multicolumn{3}{|c|}{ OS } & \multicolumn{3}{|c|}{ RFS } \\
\hline & & MST (months) & $\mathrm{HR}^{*}(95 \% \mathrm{CI})$ & $\begin{array}{c}P \\
\text { value }^{*}\end{array}$ & MRT (months) & $\mathrm{HR}^{*}(95 \% \mathrm{CI})$ & $\begin{array}{c}\mathbf{P} \\
\text { value }^{*}\end{array}$ \\
\hline \multicolumn{8}{|l|}{ ITGA5 } \\
\hline Lower & 165 & 67.4 & Ref. & 0.041 & 51.6 & Ref. & 0.006 \\
\hline Higher & 56 & 45.9 & $1.64(1.02-2.63)$ & & 21.3 & $1.75(1.18-2.62)$ & \\
\hline \multicolumn{8}{|l|}{ ITGB5 } \\
\hline Lower & 165 & 67.4 & Ref. & 0.048 & 49.1 & Ref. & 0.042 \\
\hline Higher & 56 & 53 & $1.62(1.00-2.60)$ & & 23.6 & $1.53(1.02-2.31)$ & \\
\hline \multicolumn{8}{|l|}{ ITGA2B } \\
\hline Lower & 165 & 67.3 & Ref. & 0.064 & 48 & Ref. & 0.032 \\
\hline Higher & 56 & 58.4 & $1.58(0.97-2.73)$ & & 24.6 & $1.56(1.04-2.33)$ & \\
\hline
\end{tabular}

Note: The 75th percentile of mRNA expression in the total population was used as the cutoff point to define lower and higher expression groups. *Adjusted for age, gender, cirrhosis, BCLC stage and serum AFP levels.

OS, overall survival; RFS, relapse-free survival; MST, median survival time; MRT, median relapse time; HR, hazard ratio; 95\% CI, 95\% confidence interval; Ref., reference.

Table 7: Multivariate Cox proportional hazards ratio analysis combining ITGA5 and ITGB5 expression and overall survival or relapse-free survival in $\mathrm{HBV}$-related HCC patients

\begin{tabular}{|c|c|c|c|c|c|c|c|}
\hline \multirow{2}{*}{$\begin{array}{l}\text { Groups } \\
\text { (ITTGA5 \& } \\
\text { ITGB5) }\end{array}$} & \multirow{2}{*}{$\begin{array}{l}\text { Patients } \\
(n=221)\end{array}$} & \multicolumn{3}{|c|}{ OS } & \multicolumn{3}{|c|}{ RFS } \\
\hline & & MST (months) & $\mathrm{HR}^{*}(95 \% \mathrm{CI})$ & $\begin{array}{c}\mathbf{P} \\
\text { value }^{*}\end{array}$ & $\begin{array}{c}\text { MRT } \\
\text { (months) }\end{array}$ & $\mathrm{HR}^{*}(95 \% \mathrm{CI})$ & P value \\
\hline Both Lower & 130 & 67.4 & Ref. & 0.017 & 54.8 & Ref. & 0.002 \\
\hline Lower/Higher & 70 & 53.3 & $1.37(0.84-2.25)$ & 0.212 & 36.0 & $\begin{array}{c}1.38(0.91- \\
2.07)\end{array}$ & 0.127 \\
\hline Both Higher & 21 & 17.6 & $2.58(1.34-4.95)$ & 0.004 & 13.1 & $\begin{array}{c}2.89(1.61- \\
5.18)\end{array}$ & $<0.001$ \\
\hline
\end{tabular}

Note: The 75th percentile of mRNA expression in the total population was used as the cutoff point to define lower and higher expression groups. *Adjusted for age, gender, cirrhosis, BCLC stage and serum AFP levels.

OS, overall survival; RFS, relapse-free survival; MST, median survival time; MRT, median relapse time; HR, hazard ratio; 95\% CI, 95\% confidence interval; Ref., reference.

radiation and chemotherapeutics [30]. Reports have also shown that integrins are sensitive to pharmacological blockade, making them exciting pharmacological targets for anticancer therapies [31]. Indeed, several integrin inhibitors have been designed and have undergone clinical trials, and all were shown to be nontoxic.
Some studies have shown that integrins, such as beta1, beta3 and beta5, play an important role in cell growth, proliferation, invasion and migration [31]. It has also been demonstrated that integrin levels are frequently elevated in aggressive tumors, implying that these proteins might be promising targets for cancer treatments [32]. ITGA5 is 


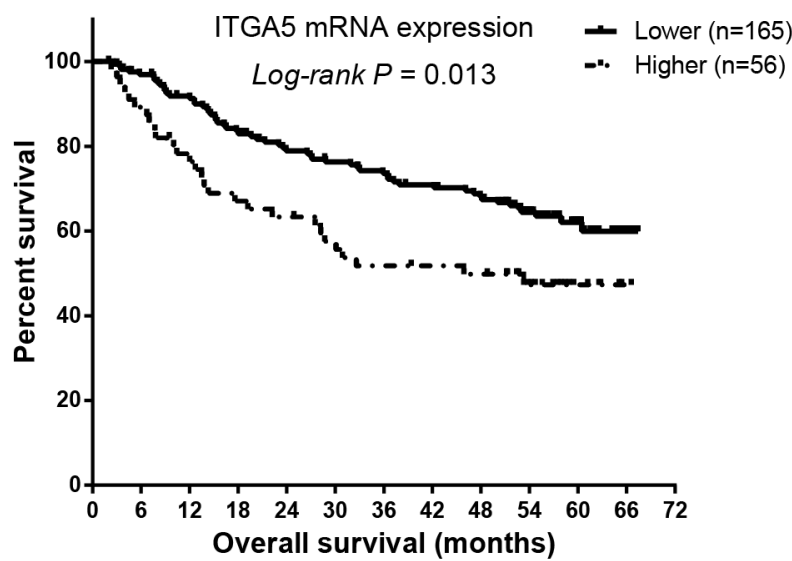

(A)

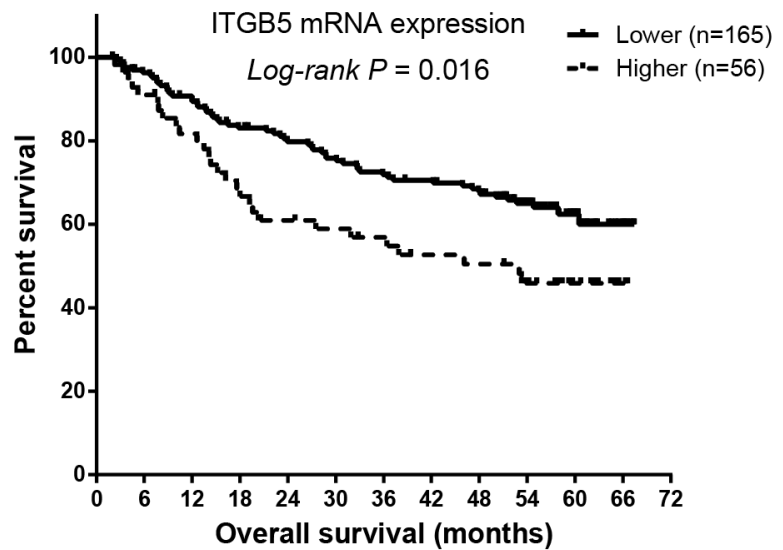

(C)

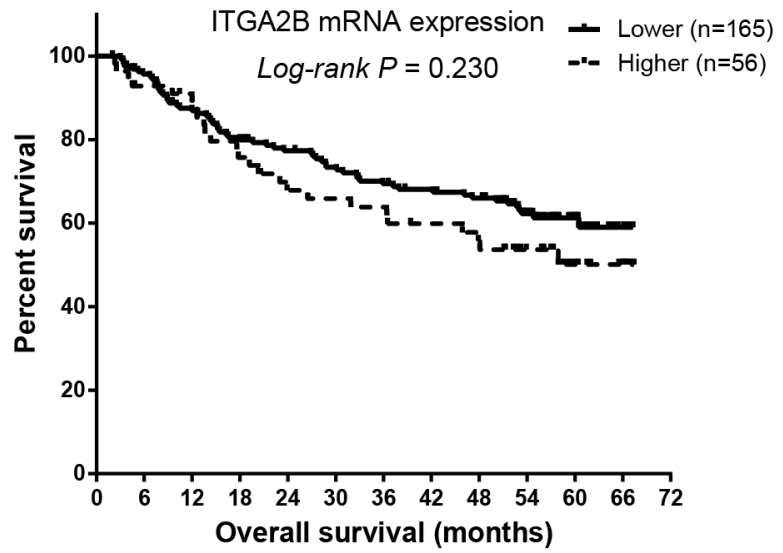

(E)

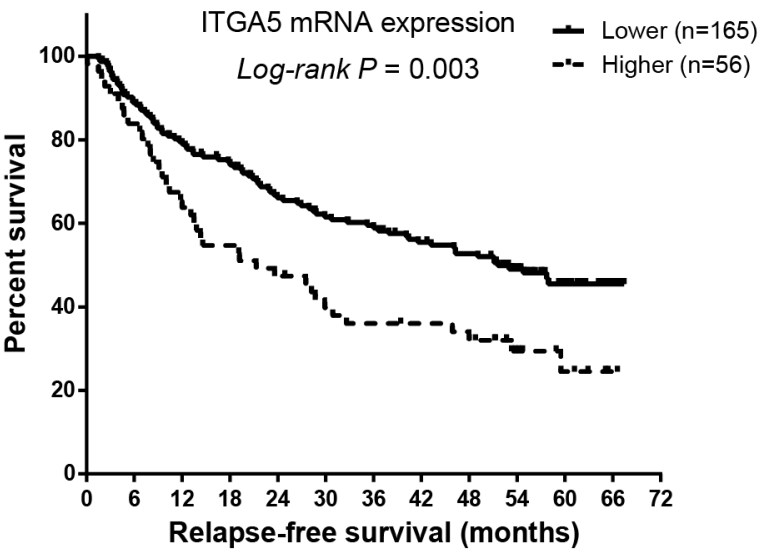

(B)

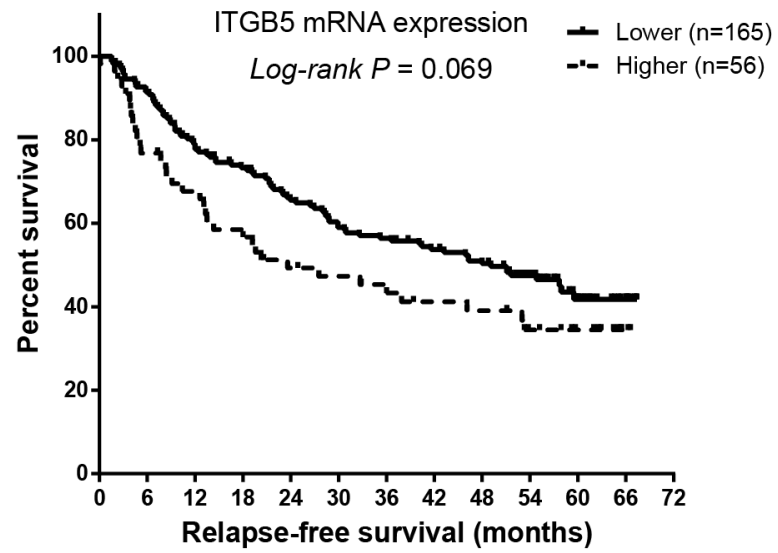

(D)

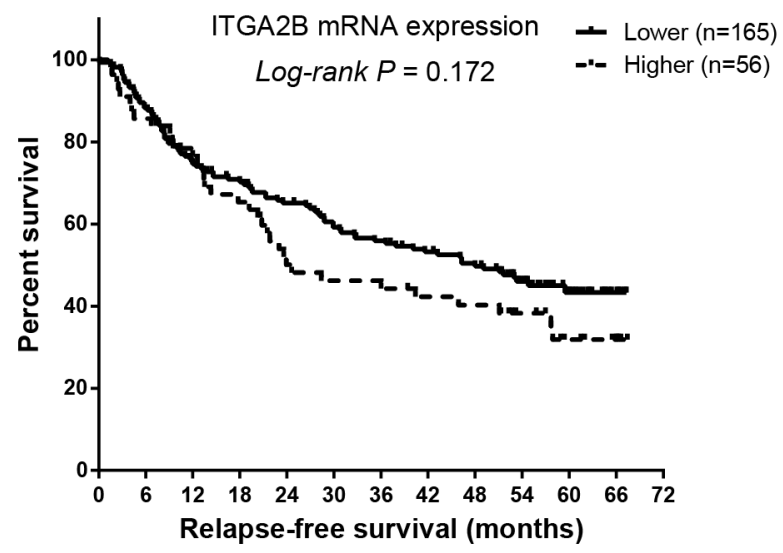

(F)

Figure 4: Prognostic value of ITGA5, ITGB5 and ITGA2B expression levels in HBV-related HCC patients. Kaplan-Meier plot representing the probabilities of overall survival and relapse-free survival in HCC patients stratified according to the expression levels of ITGA5 (A, B), ITGB5 (C, D) and ITGA2B (E, F). 
Table 8: Primers for SNPs of integrin genes

\begin{tabular}{|c|c|c|c|c|}
\hline SNPs & Primers & Sequences $\left(5^{\prime}-3^{\prime}\right)$ & $\begin{array}{c}\text { Annealing } \\
\text { temperature } \\
\left({ }^{\circ} \mathrm{C}\right)\end{array}$ & Amp Length (bp) \\
\hline rs1531545 & $\begin{array}{l}\text { Forward } \\
\text { Reverse }\end{array}$ & $\begin{array}{c}\text { ACAAGCTCTACCAGGTATCTGTATTCT } \\
\text { TTCAAGCTATGAACTGCACGTTG }\end{array}$ & 60 & 274 \\
\hline rs4145748 & $\begin{array}{l}\text { Forward } \\
\text { Reverse }\end{array}$ & $\begin{array}{l}\text { AGAGCATATTAAAAGCTTCCACCAA } \\
\text { CACCCATCCAACATGAAGACAAAG }\end{array}$ & 62 & 509 \\
\hline rs2279587 & $\begin{array}{l}\text { Forward } \\
\text { Reverse }\end{array}$ & $\begin{array}{l}\text { GAAATGGAGTCCTGAGCGCTGT } \\
\text { GGAGTGTTGAGGGCACTGCAT }\end{array}$ & 62 & 533 \\
\hline rs12520591 & $\begin{array}{l}\text { Forward } \\
\text { Reverse }\end{array}$ & $\begin{array}{l}\text { CGTTTCAAGGTAAATGAATTCCCCTAT } \\
\text { GAGGCTTAGATCTCTAAACTGATGTG }\end{array}$ & 61 & 510 \\
\hline rs988574 & $\begin{array}{l}\text { Forward } \\
\text { Reverse }\end{array}$ & $\begin{array}{c}\text { GAGGGAGGACAAGTGCACGG } \\
\text { GCAATACCAGTCACTGCTTAAGGGA }\end{array}$ & 62 & 376 \\
\hline rs2230392 & $\begin{array}{l}\text { Forward } \\
\text { Reverse }\end{array}$ & $\begin{array}{c}\text { CССТCACCCAGAATAGGAGGAGG } \\
\text { ССТССАТTТСТGССТGСТTTACA }\end{array}$ & 63 & 580 \\
\hline rs1143674 & $\begin{array}{l}\text { Forward } \\
\text { Reverse }\end{array}$ & $\begin{array}{c}\text { ATAGTGTTTGGCCCTTTTCAGGAA } \\
\text { TCTTCACTGGCAAGGCATTAAAA }\end{array}$ & 61 & 508 \\
\hline rs1143676 & $\begin{array}{l}\text { Forward } \\
\text { Reverse }\end{array}$ & $\begin{array}{l}\text { TTGGCTGGGTTTTTGTGTTTCTG } \\
\text { GACCCTGGGTCTATCTCAАCTT }\end{array}$ & 62 & 494 \\
\hline rs7562325 & $\begin{array}{l}\text { Forward } \\
\text { Reverse }\end{array}$ & $\begin{array}{c}\text { AAACCTCTAGCTAGAAGGTAAAGATCC } \\
\text { GCCCATTTTCTTGCTGGTTCTAATA }\end{array}$ & 62 & 515 \\
\hline rs11895564 & $\begin{array}{l}\text { Forward } \\
\text { Reverse }\end{array}$ & $\begin{array}{l}\text { GGAGTCCTGCTGTACTATGGTTCT } \\
\text { CAGCAGCGCTATTATTTAAACAATCA }\end{array}$ & 61 & 501 \\
\hline rs1800974 & $\begin{array}{l}\text { Forward } \\
\text { Reverse }\end{array}$ & $\begin{array}{c}\text { GTCCTCTTCCACCTTCTGCCTTT } \\
\text { CAGTGTGGCCCAGCTCTTGAC }\end{array}$ & 61 & 493 \\
\hline rs2298033 & $\begin{array}{l}\text { Forward } \\
\text { Reverse }\end{array}$ & $\begin{array}{c}\text { AATGGTTGGAATTTGGATATGAAGGAGA } \\
\text { TCTGATAGAGCACTGTGTTCACTG }\end{array}$ & 60 & 272 \\
\hline rs2507941 & $\begin{array}{l}\text { Forward } \\
\text { Reverse }\end{array}$ & $\begin{array}{c}\text { GCACTCGTGGGAAGTGGCTG } \\
\text { GGGCACAACCTGACTGAATGTC }\end{array}$ & 60 & 501 \\
\hline rs267561 & $\begin{array}{l}\text { Forward } \\
\text { Reverse }\end{array}$ & $\begin{array}{l}\text { ATCCTGTTGGTCTAGTTCTTGTTTG } \\
\text { TGGTCCAATGAGGCTTCAGTCTAG }\end{array}$ & 62 & 512 \\
\hline rs2274616 & $\begin{array}{l}\text { Forward } \\
\text { Reverse }\end{array}$ & $\begin{array}{l}\text { GGGAAGCAAACACTGGGCTTG } \\
\text { CTCCTTACCAGCACATGGAAGT }\end{array}$ & 62 & 492 \\
\hline rs2230433 & $\begin{array}{l}\text { Forward } \\
\text { Reverse }\end{array}$ & $\begin{array}{c}\text { ATTTATTTCTTTCTGGCCCACCA } \\
\text { TAAACCTGGTACCTCGGATCATACA }\end{array}$ & 60 & 410 \\
\hline rs871443 & $\begin{array}{l}\text { Forward } \\
\text { Reverse }\end{array}$ & $\begin{array}{c}\text { TAGGCACCTGTCCTTTCCTTCACC } \\
\text { GAGTCGGGAGGACGCCTAGTG }\end{array}$ & 62 & 497 \\
\hline rs2291089 & $\begin{array}{l}\text { Forward } \\
\text { Reverse }\end{array}$ & $\begin{array}{c}\text { AGCCGCACGTGCAGTTGTAG } \\
\text { GGCTGGGAAGAGGATAGGACAGAA }\end{array}$ & 62 & 494 \\
\hline
\end{tabular}

SNPs, single nucleotide polymorphisms. 
a member of the integrin family that mediates cell-to-cell adhesion, migration and anoikis in virous tumors both in vivo and in vitro $[33,34]$. Additionally, ITGA5 promotes tumor cell adhesion and migration through activating focal adhesion kinase (FAK), and an antibody (Volociximab) or a non-RGD-based peptide inhibitor (ATN-161), which blocks the function of the heterodimer function, significantly inhibits the growth and metastasis of breast cancer cells [23, 34]. ITGB5 also promotes intracellular signaling by recruiting and activating integrin-associated kinases, including FAK, which contributes to chemoresistance in malignant disease. FAK, interacting with Src at Tyr861, plays a vital role in ITGB5mediated signaling in response to vascular endothelial growth factor (VEGF) and Ras transformation in fibroblasts [31]. These features suggest that ITGB5 may participate in tumor cell adhesion, migration, inhibits metastasis, and angiogenesis, all of which may influence tumor prognosis. Our current study demonstrated that ITGB5 expression was related to $\mathrm{HBV}$-related $\mathrm{HCC}$ prognosis, and the features of ITGB5 may play a role in HBV-related HCC prognosis, but this hypothesis still need further functional experiment investigation. ITGA2B, also known as platelet glycoprotein $\mathrm{IIb}$ of the IIb/IIIa complex, is the most abundant receptor on the platelet surface [35]. By binding platelets together, it has a significant role in hemostasis. Recent studies have suggested that platelets may contribute to the spread of cancer, and cancer patients may have both an elevated number of, and activated, platelets [36]. One study also reported that the platelet glycoprotein IIb/IIIa (GP IIb/IIIa) is crucial for the hematogenous metastasis of human breast carcinoma cells [37]. Based on previous research, these functions may play a role in the prognostic of ITGA2B expression in HBV-related HCC.

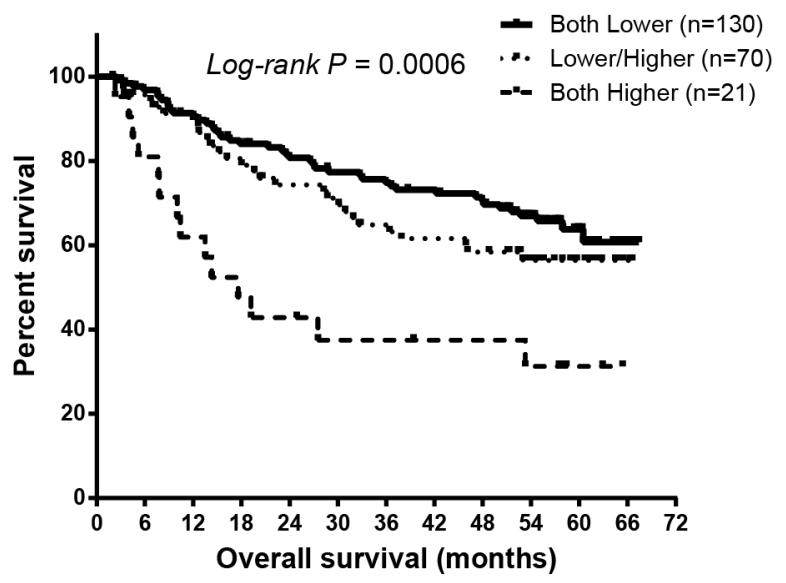

(A)
In previous reports, focus has been placed on investigating the biological behavior and prognostic roles of integrin family members in various cancers. Our results were consistent with a previous study, which found that the expression of ITGA5 was associated with the prognosis of HBV-related HCC patients [34]. Furthermore, we found that the ITGB5 expression level was higher in HCC tissues, while ITGA2B was higher in adjacent normal tissues. Furthermore, both of these genes were associated with the prognosis of HBV-related HCC patients. In addition, this is the first study to detect the prognostic predictive value of combining the expression of ITGA5 with ITGB5. Finally, we found that the AG/ GG genotypes at rs988574 (ITGA1) are significantly associated with better OS compared with carriers of the AA genotype in HBV-related HCC patients. The biggest challenge in this study was how to detect gene expression homogeneously since the data was influenced by various conditions, such as bias from the specific cell populations in the tumor tissues, the sampling sites and sample degradation, problems that have also occurred in other studies.

In summary, our study demonstrated that the expression of ITGA5, ITGB5 and ITGA2B, as well as the genotype at rs988574 (ITGA1), may be potential independent prognostic bio-markers and therapeutic targets for HBV-related HCC patients and may be useful in the diagnosis of HBV-related HCC patients. Further studies focused on integrin family members and their downstream signaling pathways, as well as the effective blockage of integrins and their ECM interactions, will provide additional information about their use in cancer therapies.

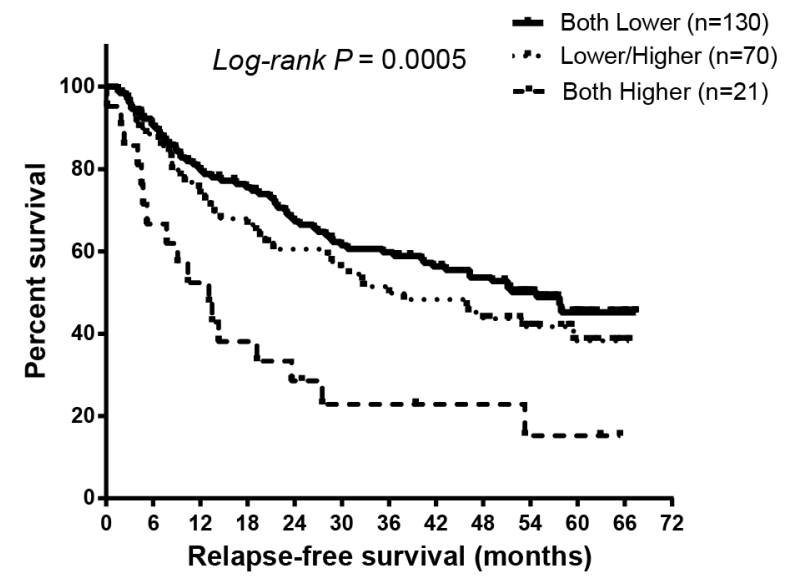

(B)

Figure 5: Prognostic value of ITGA5 expression combined with ITGB5 expression in HBV-related HCC patients. Kaplan-Meier plots showing the overall survival (A) and relapse-free survival (B) of combining ITGA5 and ITGB5 mRNA expression. 


\section{METERIALS AND METHODS}

\section{Ethical approval}

This study was performed in support of the Ethical Review Committee of the First Affiliated Hospital of Guangxi Medical University (Guangxi, China), and informed consent was obtained from all patients.

\section{Study population}

A total of 485 newly diagnosed pathologically confirmed HBV-related HCC patients that had undergone surgical resection were recruited at the First Affiliated Hospital of Guangxi Medical University (Guangxi, China) from January 2005 to September 2014. All the patients were diagnosed by histopathological examination which followed the National Comprehensive Cancer Network $(\mathrm{NCCN})$ clinical practice guidelines for oncology. The patients were followed up via telephone or hospital visit until death or final follow-up in September 2014, for a median follow-up time of 47 months. None of the patients had a previous cancer diagnosis of any kind at the initial screening examination. The clinicopathological characteristics of patients including age, gender, smoking status, drinking status, pathological grade, biobehavior of their cancer, serum AFP level, hepatic cirrhosis, radical resection and use of transcatheter hepatic arterial chemoembolization (TACE) were obtained from medical records and pathological reports. Tumor status was classified according to the BCLC staging system. ChildPugh class was defined as previously published. Portal vein tumor thrombus (PVTT) was determined to be absent or present. The endpoint was overall survival (OS), which was calculated from the date of pathological diagnosis/ recruitment to death or the end of follow-up.

\section{SNP selection, DNA extraction and genotyping}

SNP selection tools (http://snpinfo.niehs.nih.gov/ snpinfo/snpfunc.htm) were used to select candidate SNPs in integrin genes according a previous publication. The inclusion criteria were as follows: (i) SNPs in splice sites and CDS regions resulting in amino acid changes; SNPs in transcription factor binding sites of the 5' flanking region; and SNPs in miRNA binding sites of 3' UTR; and (ii) SNPs with minor allele frequency (MAF) $\geq 10 \%$ in the Han Chinese population (CHB) from the 1000 Genomes Project (March 2012, build GRCh37/hg19) [38]. These criteria resulted in 18 SNPs being identified for assessment in this study (Table 8).

HCC tissues collected after surgical resection from HBV-related HCC patients were immediately stored at $-80^{\circ} \mathrm{C}$ until DNA extraction using the TIANamp Genomic DNA Kit (Tiangen Biotech, Beijing, China), and genotyping was performed using Sanger DNA sequencingby Shanghai Sangon Biological Engineering Technology \& Services (Shanghai, China). All primers are shown in Table 8.

\section{Integrin gene mRNA expression analyses in HBV-related HCC tissues}

In the present study, we focus on the Chinese HBV-related HCC. The Gene Expression Omnibus (GEO) data selection criteria were set as follows: (i) expression profiling chip; (ii) Chinese HBV-related HCC; (iii) corresponding survival profiles available; (iv) patients undergoing hepatectomy. By searching the GEO database, we found that only the data of GSE14520 met the above criteria. Data were analyzed with Expression Console software (http://www. affymetrix.com/estore/index.jsp). Probe signal values were converted to $\log 2$ values, and annotated genes were analyzed using the corresponding Affymetrix HT Human Genome U133A and Human Genome U133A_2 array annotation files. A multi-array average algorithm was used for normalization of the GSE14520 mRNA expression data. We analyzed the association between the mRNA expression of integrin genes and prognosis in $221 \mathrm{HBV}$-related HCC patients using data from the GSE14520. The 75th percentile was used to define higher versus lower expression.

\section{Statistical analysis}

The pearson correlation coefficient was used to assess the co-expression correlation of integrin genes in tumor mRNA. OS was defined as the time from surgery to death due to HCC and relapse-free survival (RFS) was defined as the time from surgery to disease recurrence. Hazard ratios (HRs) and 95\% confidence intervals (CIs) were estimated by the Cox proportional hazards model after adjusting for factors such as age, gender, AFP level, tumor differentiation and treatment after surgery. GraphPad Prism 6 was used to plot Kaplan-Meier survival curves, scatter diagrams and histograms. Differences in the mRNA expression of integrin genes between HCC tissues and non-HCC tissues were evaluated using Student's t-test. Statistical significance was set at a level of $P=$ 0.05 , and all analyses were done using SPSS version 18.0 (SPSS, Inc., Chicago, IL, USA).

\section{Author contributions}

Liming Shang and Tao Peng designed this manuscript; Liming Shang, Xinping Ye, Guangzhi Zhu, Hao Su, zhixiong Su, Bin Chen, Kaiyin Xiao, Lequn Li, Minhao Peng and Tao Peng conducted the study, collected the tumor specimens and corresponding patients clinical data, follow-up and analyzed the data. Liming Shang wrote this manuscript and Tao Peng guided the writing. 


\section{Abbreviations}

HCC, hepatocellular carcinoma; SNPs, single nucleotide polymorphisms; PCR, polymerase chain reaction; HBV, hepatitis B virus; SNPs, single nucleotide polymorphisms; OS, overall survival; RFS, recurrence-free survival; AFP, serum alpha fetoprotein; PVTT, portal vein tumor thrombosis; MAF, minor allele frequency; CDS, coding sequence; GEO, Gene Expression Omnibus; HR, hazard ratios; 95\% CI, 95\% confidence interval; MST, median survival time; MRT, median recurrence time.

\section{ACKNOWLEDGMENTS}

This work was supported in part by the National Natural Science Foundation of China (NSFC 81560535, $81072321,30760243,30460143$, and 30560133), the 2009 Program for New Century Excellent Talents in University (NCET), a Guangxi Natural Sciences Grant (GuiKeGong 1104003A-7), and a Guangxi Health Ministry Medicine Grant (Key Scientific Research Grant Z201018). The authors thank the contributors of the GSE14520 for sharing their dataset on open access. In addition, We also would like to acknowledge the helpful comments on this paper received from our reviewers.

\section{CONFLICTS OF INTEREST}

The authors do not have any conflicts of interest.

\section{REFERENCES}

1. Siegel RL, Miller KD, Jemal A. Cancer statistics, 2016. CA Cancer J Clin. 2016; 66:7-30.

2. Wang Z, Wang J, Wang Q, Wang J, Yuan J, Si Y. A genetic variant in DICER gene is associated with prognosis of hepatocellular carcinoma in a Chinese population. Hepatol Res. 2016.

3. Fan C, Jin G, Sun C, Ma D, Chen C, Qiao P, Wu D. Clinical characteristics, treatment patterns and survival outcome of hepatocellular carcinoma patients aged 70 years or older: a single-center retrospective study from China. Aging Clin Exp Res. 2014; 26:123-130.

4. Chen XP, Huang ZY. Surgical treatment of hepatocellular carcinoma in China: surgical techniques, indications, and outcomes. Langenbecks Arch Surg. 2005; 390:259-265.

5. Choi KJ, Baik IH, Ye SK, Lee YH. Molecular targeted therapy for hepatocellular carcinoma: present status and future directions. Biol Pharm Bull. 2015; 38:986-991.

6. Qiao W, Yu F, Wu L, Li B, Zhou Y. Surgical outcomes of hepatocellular carcinoma with biliary tumor thrombus: a systematic review. BMC Gastroenterol. 2016; 16:11.

7. Grandhi MS, Kim AK, Ronnekleiv-Kelly SM, Kamel IR, Ghasebeh MA, Pawlik TM. Hepatocellular carcinoma: from diagnosis to treatment. Surg Oncol. 2016; 25:74-85.
8. Janevska D, Chaloska-Ivanova V, Janevski V. Hepatocellular carcinoma: risk factors, diagnosis and treatment. Open Access Maced J Med Sci. 2015; 3:732-736.

9. Llovet JM, Bruix J. Early diagnosis and treatment of hepatocellular carcinoma. Baillieres Best Pract Res Clin Gastroenterol. 2000; 14:991-1008.

10. Testino G, Leone S, Patussi V, Scafato E, Borro P. Hepatocellular carcinoma: diagnosis and proposal of treatment. Minerva Med. 2016; 107:413-426.

11. Li Z, Zhao X, Jiang P, Xiao S, Wu G, Chen K, Zhang X, Liu H, Han X, Wang S, Li X. HBV is a risk factor for poor patient prognosis after curative resection of hepatocellular carcinoma: a retrospective case-control study. Medicine. 2016; 95:e4224.

12. Su L, Zhou T, Zhang Z, Zhang X, Zhi X, Li C, Wang Q, Jia C, Shi W, Yue Y, Gao Y, Cheng B. Optimal staging system for predicting the prognosis of patients with hepatocellular carcinoma in China: a retrospective study. BMC Cancer. 2016; 16:424.

13. AlSalloom AA. An update of biochemical markers of hepatocellular carcinoma. Int J Health Sci. 2016; 10:121-136.

14. Sun $\mathrm{CC}, \mathrm{Qu} \mathrm{XJ}, \mathrm{Gao} \mathrm{ZH}$. Integrins: players in cancer progression and targets in cancer therapy. Anticancer Drugs. 2014; 25:1107-1121.

15. Hynes RO. Integrins: bidirectional, allosteric signaling machines. Cell. 2002; 110:673-687.

16. Foubert P, Varner JA. Integrins in tumor angiogenesis and lymphangiogenesis. Methods Mol Biol. 2012; 757:471-486.

17. Lorger M, Krueger JS, O'Neal M, Staflin K, FeldingHabermann B. Activation of tumor cell integrin alphavbeta3 controls angiogenesis and metastatic growth in the brain. Proc Natl Acad Sci U S A. 2009; 106:10666-10671.

18. Schlaepfer DD, Hunter T. Focal adhesion kinase overexpression enhances ras-dependent integrin signaling to ERK2/mitogen-activated protein kinase through interactions with and activation of c-Src. J Biol Chem. 1997; 272:13189-13195.

19. Campbell ID, Humphries MJ. Integrin structure, activation, and interactions. Cold Spring Harb Perspect Biol. 2011; 3.

20. Bianchi A, Gervasi ME, Bakin A. Role of beta5-integrin in epithelial-mesenchymal transition in response to TGF-beta. Cell Cycle. 2010; 9:1647-1659.

21. Ruegg C, Alghisi GC. Vascular integrins: therapeutic and imaging targets of tumor angiogenesis. Recent results in cancer research Fortschritte der Krebsforschung Progres dans les recherches sur le cancer. 2010; 180:83-101.

22. Lesniak D, Xu Y, Deschenes J, Lai R, Thoms J, Murray D, Gosh S, Mackey JR, Sabri S, Abdulkarim B. Beta1-integrin circumvents the antiproliferative effects of trastuzumab in human epidermal growth factor receptor-2-positive breast cancer. Cancer Res. 2009; 69:8620-8628.

23. Desgrosellier JS, Cheresh DA. Integrins in cancer: biological implications and therapeutic opportunities. Nat Rev Cancer. 2010; 10:9-22. 
24. Winograd-Katz SE, Fassler R, Geiger B, Legate KR. The integrin adhesome: from genes and proteins to human disease. Nat Rev Mol Cell Biol. 2014; 15:273-288.

25. Cabodi S, Di Stefano P, Leal Mdel P, Tinnirello A, Bisaro B, Morello V, Damiano L, Aramu S, Repetto D, Tornillo G, Defilippi P. Integrins and signal transduction. Adv Exp Med Biol. 2010; 674:43-54.

26. Garmy-Susini B, Varner JA. Roles of integrins in tumor angiogenesis and lymphangiogenesis. Lymphat Res Biol. 2008; 6:155-163.

27. Nemeth JA, Cher ML, Zhou Z, Mullins C, Bhagat S, Trikha M. Inhibition of alpha(v)beta3 integrin reduces angiogenesis, bone turnover, and tumor cell proliferation in experimental prostate cancer bone metastases. Clin Exp Metastasis. 2003; 20:413-420.

28. Genersch E, Ferletta M, Virtanen I, Haller H, Ekblom P. Integrin alphavbeta3 binding to human alpha5-laminins facilitates FGF-2- and VEGF-induced proliferation of human ECV304 carcinoma cells. Eur J Cell Biol. 2003; 82:105-117.

29. Mochmann LH, Neumann M, von der Heide EK, Nowak V, Kuhl AA, Ortiz-Tanchez J, Bock J, Hofmann WK, Baldus CD. ERG induces a mesenchymal-like state associated with chemoresistance in leukemia cells. Oncotarget. 2014; 5:351-362. https://doi.org/10.18632/oncotarget.1449.

30. Kim HS, Kim SC, Kim SJ, Park CH, Jeung HC, Kim YB, Ahn JB, Chung HC, Rha SY. Identification of a radiosensitivity signature using integrative metaanalysis of published microarray data for NCI-60 cancer cells. BMC Genomics. 2012; 13:348.
31. Wang S, Xie J, Li J, Liu F, Wu X, Wang Z. Cisplatin suppresses the growth and proliferation of breast and cervical cancer cell lines by inhibiting integrin beta5mediated glycolysis. Am J Cancer Res. 2016; 6:1108-1117.

32. Kapp TG, Rechenmacher F, Sobahi TR, Kessler H. Integrin modulators: a patent review. Expert Opin Ther Pat. 2013; 23:1273-1295.

33. Qin L, Chen X, Wu Y, Feng Z, He T, Wang L, Liao L, Xu J. Steroid receptor coactivator-1 upregulates integrin alpha(5) expression to promote breast cancer cell adhesion and migration. Cancer Res. 2011; 71:1742-1751.

34. Zhang X, Cheng SL, Bian K, Wang L, Zhang X, Yan B, Jia LT, Zhao J, Gammoh N, Yang AG, Zhang R. MicroRNA26a promotes anoikis in human hepatocellular carcinoma cells by targeting alpha5 integrin. Oncotarget. 2015; 6:2277-2289. https://doi.org/10.18632/oncotarget.2956.

35. Rivera J, Lozano ML, Navarro-Nunez L, Vicente V. Platelet receptors and signaling in the dynamics of thrombus formation. Haematologica. 2009; 94:700-711.

36. Jain S, Harris J, Ware J. Platelets: linking hemostasis and cancer. Arterioscler Thromb Vasc Biol. 2010; 30:2362-2367.

37. Zhao F, Li L, Guan L, Yang H, Wu C, Liu Y. Roles for GP IIb/IIIa and alphavbeta3 integrins in MDA-MB-231 cell invasion and shear flow-induced cancer cell mechanotransduction. Cancer Lett. 2014; 344:62-73.

38. Han C, Yu L, Liu X, Yu T, Qin W, Liao X, Liu Z, Lu S, Chen Z, Su H, Zhu G, Qin X, Gui Y, et al. ATXN7 gene variants and expression predict post-operative clinical outcomes in hepatitis B virus-related hepatocellular carcinoma. Cell Physiol Biochemy. 2016; 39:2427-2438. 